\title{
A Snapshot of Haryana's Dynamics in The Mughal Period Mamta Rani1 ${ }^{1}$, Dr. Altaf Khan ${ }^{2}$ \\ ${ }^{1}$ Research Scholar, Department of History, Madhav University, Rajasthan, India \\ ${ }^{2}$ Research Supervisor, Department of History, Madhav University, Rajasthan, India
}

\begin{abstract}
Haryana has been a focus of attention throughout history, including the ancient, medieval, and modern periods. Because of its location in the north, it remained strategically important. During the Sultanate and Mughal periods, the Haryana district was extremely important in terms of trade and resistance. In ancient times, the Mahabharata was fought at Kurukshetra, and three skirmishes at Panipat, which completely transformed India's fortunes, were fought in Haryana. This study intends to contribute to the socioeconomic and unique situations of the Haryana region during the Mughal period in an objective and scientific manner (1707-1857). This period of Mughal history was chosen for research because it was a time of great change, replete with perplexity, curiosity, and upheaval. This time, the sunset represented the rise and collapse of the Sikhs', Marathas', and Jats' powers, as well as the rise and power of the theory British. It is concerning that the region's historical realities, socioeconomic, and religious problems are not fully recognized, despite attempts in both cases. This revelation was necessary in order to showcase a larger network of regional opportunities and to portray the genuine image of the time. The analysis attempts to close this gap in this way. It will also respond to the ever-changing demand, as well as the necessity to rewrite and recompose the regional history in light of the wide range of expertise and education now accessible.
\end{abstract} Keywords : Haruyana, Mugal Period, Economic Condition

\section{INTRODUCTION}

Gupta Empire, Pushyabhuti Dynasty, GurjaraPratihara Dynasty, Tomara Dynasty, Chahamanas of Shakambhari, Ghurid Dynasty, Delhi Sultanate, Mughal Empire, Durrani Empire, Maratha Empire, (George Thomas), Gwalior State, Company Rule in India, and British Raj have all ruled over Haryana. Haryana was known as Delhi Subah under the Delhi Sultanate and the Mughal Empire. It has seen many historically notable engagements, including the Battle of Tarain, the Battle of Panipat, and the Battle of Karnal.
Haryana passed to the Maratha Empire after the Mughals. Haryana was acquired by the British Empire after the Surji-Anjangaon Treaty of 1803, and was afterwards combined with the North West Provinces. As a punishment for the uprising of 1857, Haryana, then known as Delhi Territory, was amalgamated with Punjab Province in April 1858. (https://en.wikipedia.org/wiki/History of Haryana, Mughal Empire)

Despite the territory's strategic location and importance, the region and its history have been neglected and muddled. It did not receive the attention that it deserved from historians. It was only 
in the last few years that historians (mostly from this region) began to carve out and reconstruct the region's history. Haryana has always been overlooked and has never had the same historical significance as Bengal or Punjab. This was owing to the fact that Haryana was never an independent political entity in the sense that it is today. Alternatively, Haryana state has never existed as a composite administrative unit. In historical works, it has always been regarded as a subregion or a sub-tract. It was mainly associated with Delhi, the northwestern province of Canada, or Punjab. Even after India's independence from the United Kingdom in 1947. Haryana had been neglected for a long time. It remained a part of the undivided Punjab and had always taken a back seat.

The time period chosen for our investigation (1707 to 1857) was a turbulent one, with the end of Mughal control, the rise and collapse of Sikh, Maratha, and Jat empires, and the advent and dominance of British rule in Haryana. It is a crossroads between the medieval and contemporary periods of history. The period (1707-1857) can be divided into three distinct phases. The first phase spans the years 1707 to 1761 , while the second spans the years following the Battle of Panipat and ending with the Britishers' capture of Haryana in 1803. Period III begins in 1803 and ends in 1857 with the uprising.

\section{NEED OF THE STUDY}

For a long time, history students focused on the research of regional political history as it related to war and combat. Lately, the social, economic, and social history has been expected to be more noteworthy than the political history. As a result, this investigation has been undertaken in order to provide additional information about Haryana's social, economic, religious, and societal history throughout the latter Mughal times. Despite Haryana's significant contributions to the nation in a number of areas, the region has largely escaped the scholars' attention when it comes to assembling the historical backdrop of the region during the latter Mughal period.

\section{The following are the research study's key goals:}

1. To research the political history of Haryana during the Mughal era.

2. To gain a better understanding of Haryana's culture and architecture during the Mughal period.

\section{RESEARCH METHODOLOGY}

The term "research methodology" refers to a way for dealing with a research problem in a systematic manner. Any research's objectives are realized through the use of appropriate research methodology. The term "methodology" refers to the research plan as well as the tactics used to collect records, data, and materials. It should be remembered that the research design should be good in terms of source material accessibility. For the objective of this study, a literature review technique was used.

\section{RESEARCH DESIGN}

Our investigation will use a hybrid research design that combines descriptive and explorative research methods. This presents and investigates the characteristics of individuals, groups, and experts. This composite type of design encompasses the vast bulk of social research (chronicled study). As the situation necessitates, this type of design provides equal weight to accumulating current facts and also proceeds to study all new facts. It is a rigid design that requires sufficient planning to protect and ensure against tendency, ensuring maximum dependability.

\section{DATA COLLECTION}

History isn't just a recitation of previous events of activities and transgressions by decision-makers; it also emphasizes social institutions, their economic, religious, and cultural contexts. Historical study is 
becoming far more accessible to the general people as a result of this new paradigm. If Haryana had occurred, the historical realities of Mughal history would have been truly amazing; but, the historical truths of the later Mughal period, to which our investigation pertains, were neglected and covered up in order to expedite the surface. It is a fundamental understanding of the problem as well as the preservation of data relevant to the topic.

\section{HARYANA DURING THE MUGHALE PERIOD}

Haryana's history was crucial during the Mughal era. During the Mughal Empire, wars were fought in the Haryana district, which is located between Lahore and Delhi. Babur established the Mughal Empire in India in 1526 in the battlefield of Panipat. During the time of Babur's assaults, India was a lonely place. Babur launched a major campaign against India in the final days of 1525, gaining leeway for maneuvering in the face of chaotic circumstances. He crossed the Punjab without gathering armies and arrived in Ambala in early 1526. From there, Babur traveled through Shahabad and along the Yamuna in Tehsil Pipli Alahar, following the river's edge until Karnal. After a brief halt in Gharunda, take a break. Babur's troops marched to Panipat. He chose this one for the battleground (Singh, 1981). On April 21, 1526, Ibrahim Lodhi's men went on strike, but were entirely commanded by Babur's army as they sought for Delhi. Unlike the Mughals in terms of discipline, will, and courage, as well as their peerless officer Ibrahim, the Afghan army was composed of 100,000 warriors and 1,000 elephants, mostly made up of mediocre mercenaries and unsurpassed in terms of relationship with Jahiruddin Babur. Ibrahim died bravely in the first row.

\section{(firedirectioncenter.blogspot.com).}

By overthrowing Sultan Ibrahim Lodhi, Babur undoubtedly established a powerful and devoted Hindustani throne. In any case, the inhabitants of Haryana did not send them out week after week. His expectations for Haryana, on the other hand, were not met. The Mandhar Rajputs of Haryana's Nardak area revolted in 1529 and conquered the neighboring Mughal waters under the patronage of Mohan. Babur became enraged and attacked and killed some of his rebels, as well as robbing their villages (Chandra, 2005).

To maintain the smooth running of one unit, Babur divided Haryana into four Sarkars, the majority of which were based in Sirhind. Hissar-I-Firuzah, Minat, and Delhi are three of the most important cities in the Islamic world. These Sarkars became wealthy and established estates as a result of their contributions to the empire. After Babur's death (December 26, 1530), Humayun accepted Hindustan's reign and governed for ten years until Sher Shah Suri (born in Narnaul) tormented him and forced him out of India in 1540. Agra and Delhi accompanied Hemu, an Adil Shah general stationed in Rewari, to Panipat to battle and destroy the Mughals (panipat.gov.in). Although Akbar did not wish to confront Hemu, he did so in the case of Bairam Khan, one of Akbar's officers. Hemu battled valiantly the day his fatal lightning bolt struck his eye and knocked him out in his elephant's howdah, and his transmission had every chance of being true. His troops betrayed him and fled to get closer to Akbar.

As a result of their stubborn and sovereign thoughts, Akbar, the most powerful of the Mughals, despised the people here. In fact, he enjoyed seeing her struggle. Nizamuddin exhibits this effect in his book TahqatIAkbari (1567 AD). Haryana experienced peace and prosperity during the reigns of Jahangir and Shah Jahan. The candid Jahangir's social actions aided Haryana's citizens. The number of sarais, miners, roadways, and shafts was counted, and Haryana's dark trees were planted along the roadside. Haryana experienced a period of relative calm. However, it appeared that frequent and deadly periodic cataclysms tended to wreak havoc on the lives of those living near open pit mines. Abdullah al Abbasis Safarnama, a respected Gujarati scholar, is a key figure in Haryana's history during the first part of the 17th century AD. 
Many areas in Haryana, such as Narnaul with Sirhind guaranteed, are part of his program, which runs from Sambhar through Ludhiana and then to Delhi. Kaithal, Hisar-IFiruza, Meham, Thanesar, Jind, and Panipat are all places in India. Another historian, Latif, mentions Jahangir's desire for structures to be built on the banks of the Sannihit reservoir in Kurukshetra. Narnaul, who framed a piece from Agra Suba, was completely rendered by Latif. It was tightly controlled. Greetings, Latif. The planet Narnaul bore no resemblance to Narnaul. It hit him like the world's sky had fallen in on him (Baden, 1969).

In any case, Aurangazeb had done little for the kingdom at the time, unlike his predecessors, and he was hostile towards Mewatis and Satnamisb as a result of his riots and the district's obvious ties to Dara. Aurangzeb had not yet developed the ability to take a repressive approach to this situation. As a result of this kind of Aurangzeb control, the Mughal Empire collapsed, causing unrest among Hindus and other people in the area. The reportage of Mewatis and Satnamis did not change the pervasive and oppressive perception of prejudice. It has also obliterated the region's sacred places. Some shrines were razed and a palace dubbed Mughalpura was ruled at Kurukshetra, in the middle of a lake from which Mughal warriors could fire spies who came to wash. With columns on all four sides, the remaining elements of the palace are now accessible for defense.

The Oppression Principle of Aurangzeb. During the typical Maratha period in Haryana, the Kurukshetra temples were built, replicated, or rebuilt. (Calcutta, 1882).

\section{ECONOMIC CONDITION OF HARYANA DURING MUGHAL ERA}

Haryana was primarily a flat plain during the Mughal time, as it is now. Only the Shivalik and Aravalli hills in the north and south, as well as some sand dunes in the west and south-west, are present. Only the
Yamuna is a year-round flowing river. A river ran through the area. Which used to flow, defining the region's eastern limit. But there were also rainy rivers, such as the Ghaggar, Saraswati, Chautang, and Markanda in the north, and the Sahabi, Kasavati, and Dohan, among others, in the south. The terrain was fertile, but due to a lack of rainfall and a lack of twelve-monthly flowing rivers for irrigation, agriculture was not advanced. Of course, this region was known for its livestock.

The system of land rents System of land rents: The system of land rents System of bhoot rent System of bhoot rent During the Mughal Empire, during the reign of Babur, the farmers of Haryana region's rent was likely increased by $50 \%$, making the farmers unhappy. As a result, he had to deal with strong opposition from farmers in northern Haryana. Sher Shah Suri, on the other hand, sought in his limited time to improve the farmers' situation. He'd set aside a third of the rent. Following Sher Shah, Akbar focused his efforts on improving the farmers' situation. In the Haryana region, Akbar arranged for the "Zabti method" to evaluate land tax. His Diwan Muzaffar Khan and Todar Mal taught him this system. Akbar's goal in putting this system in place was to I fix the state's share on a firm foundation, and (1) create a system that gave the state's portion in cash and commodities such that no one was hurt by the state or the farmers. (2). To establish such arrangements for commodity prices that the state can have a precise estimate of its annual revenue.

The rate of rent changed slightly after Akbar, under the reigns of Jahangir and Shah Jahan. However, Aurangzeb's circumstances forced him to raise the land tax in order to gather wealth. He had to engage in lengthy battles. For this he required funds. He placed various other levies on farmers, such as jizya, in addition to raising the land tax. As a result, Aurangzeb had to deal with peasant uprisings in several locations. 
The Satnamis and the Jats of Ballabhgarh both revolted. Following Aurangzeb, Bahadur Shah attempted to improve the situation by emulating Akbar's policies. However, there was no success. Following Bahadur Shah, his successor raised the rent rate to $2 / 5$ part. However, no one paid taxes back then. After harvesting, Bhumikar was gathered twice a year. To correct the land tax, the Mughals used the confiscation method. In the pargana, the work of collecting land tax was used. Kanungo, Patwari, and a few other workers were on hand to assist him. There was no tax on land that had no farmers. The monopoly method was used to collect land tax after Bahadur Shah. A contract was issued to collect land tax as a result of this. It was a system based on exploitation. The system could not function well under weak rulers, and there was constant struggle between the subjects and these monopolies. On the strength of their power, large monopolies used to collect entire revenue. The rate of recovery was also higher than $2 / 5$ in certain regions, which was beyond the farmers' ability to pay. As a result, farmers revolted in some places, while others were exploited.

(http://mdudde.net/pdf/study_material_DDE/ma/ma_ history/History\%20of\%20Haryana-final.pdf)

\section{REVIEW OF LITERATURE ON HARYANA HISTORY}

Singh (2012) examines "Dalits in Haryana Politics" and demonstrates that Dalits add to the self-control variables in state legislative affairs. Dalits were introduced as a self-supervision element in the Haryana provincial assortments. Dalit authentication is in the original structure in most Haryana districts, particularly Jat-dominated areas like Rohtak, Bhiwani, Hisar, Jind, Sonepat, and others.

Outsiders from outside the territory, as well as residents from different sections of the country, have been misled to protect the Haryana district. "Nadir Shah and Ahmed Shah Abdali stormed this region of the country, stealing and destroying all they could find.
In 1761, the third Panipat encounter, perhaps India's bloodiest conflict, took place in Haryana (theprint.in). The people and civilization of this district have been forever changed as a result of these attacks and wars. Furthermore, European trade organisations from Portugal, France, the United Kingdom, and the Netherlands were enthusiastic about the Haryana district, having expanded their activities and influence in India. The fall of the Mughal Emperor provided them with a once-in-a-lifetime opportunity to send God, and the British seized control of the territory and conquered it. In Haryana, George Thomas and Charles Metcalfe attempted to form a common union. In 1803 the East India Company also gained control of the Haryana region. The British alliance knew how to help the Mughal emperor's position. The British gradually solidified their position in Haryana and established themselves as experts in the area." (Dalrymple, 2013).

\section{CONCLUSION}

The purpose of this study was to relate the socioeconomic and other aspects of the Haryana region during the late Mughal period in an impartial and scientific manner (1707-1857). This sub-period of Mughal history was chosen for research because it was a chaotic age filled with confusion, intrigues, and turbulences. This was an era of transition, with the demise of the Mughal Empire, the rise and fall of the Sikhs, Marathas, and Jats, and the establishment and dominance of British control. This one-hundred-andfifty-year period between two empires, the later Mughal and the British, had been a haven for free robbers, including foreign invaders like Nadir Shah and Ahmad Shah Abdali. They terrorized the countryside and committed rapine, causing the population to suffer greatly and confront hardship, disorder, and anguish. During this time, the local people rose to the occasion and sacrificed their lives while defending their motherland, demonstrating their patriotism. 
To summarize, the latter Mughal period can be described as a long period of socio-economic instability and unrest. This was the saddest and most horrible moment in Haryana's history. Haryanvis faced enormous deprivation, misery, tyranny, helplessness, brutal exploitation, agony, and outrage during this period of turmoil, social, and severe economic upheaval, with little quick hope of redemption. Both the Mughals and the British were unconcerned about the people of this region. During the one hundred and fifty years covered by our study, the region continued to suffer and groan.

\section{REFERENCES}

[1]. Agnew R. (1992) foundation for a general strain theary of crime and delinquency criminology.

[2]. Arneklev B. J. Grasmick H. G. Tittle C. R. -8 Bursik R. J. (1993) law self-control and imprudent behavior journal of quantitative criminology. 225,247

[3]. Burton V. S. oullen F. T. Evans. T. D. Alarid L.F. \& Dunaway R. G. (1998) Gender self-control and crime journal of research in crime and delinquency. 05,123,147

[4]. Guenther C. L. and M.D. Alicke-2013 psychology of he self in oxford bibliographies in psychology new York oxford university press.

[5]. james W. 1890 the consciousness of self in the principles of psychology vol.1 by w. james. 291401 new York Henry Hots.

[6]. Leary M.R. and J. P. Tangney, eds. 2012 Handbook of self and identity 2nd new York Guilford.

[7]. Asiely D. and K. wertenbroch 2002. procrastination deadlines and performance selfcontrol by recommitment psychological science 13.3 219-224.

[8]. Aspinarall L. G. and S. E. Taylor. 1997. Astiten in time self-regulation and proactive coping psychological bulletin 121.3. 417-436.
[9]. Amir N. C. Beard M. Buens and J. Bomyea 2009 Attention modification program in individuals with generalized anxiety disorder. Journal of abnormal psychology 118.1 28-33.

[10]. Fujit K. Y. Trope N. Liberman and Levin sagi 2006. construal levels and self-control journal of personality and social psychology 90.3 351-367.

\section{Cite this article as :}

Mamta Rani, Dr. Altaf Khan, "A Snapshot of Haryana's Dynamics in The Mughal Period'", International Journal of Scientific Research in Science and Technology (IJSRST), Online ISSN : 2395-602X, Print ISSN : 2395-6011, Volume 6 Issue 1, pp. 636-641, January-February 2019. Available at doi : https://doi.org/10.32628/IJSRST1962353

Journal URL : https://ijsrst.com/IJSRST1962353 